\title{
Good Kings, Bloody Tyrants, and Everything In Between: Representations of the Monarchy in Post-Genocide Rwanda
}

\author{
Erin Jessee and Sarah E. Watkins
}

\begin{abstract}
In the post-genocide period, President Paul Kagame and his political party, the Rwandan Patriotic Front, are struggling to unite Rwanda's citizens using, among other initiatives, a simplified version of Rwandan history to diminish the ethnic tensions that made the 1994 genocide possible. As a result, Rwanda's history has become highly politicized, with vastly divergent versions of the nation's past narrated in private settings, where it is more politically appropriate for Rwandans to share their experiences. This paper focuses on divergent representations of Rwandan monarchical figures \#\# often unnamed \#\# whom the narrators imbue with values according to their individual political affiliations, lived experiences, and identity. These narratives are indicative of the broader ways that modern Rwandans narrate their experiences of history in response to Rwanda's current official history, as well as previous official histories. Careful analysis reveals much about the current political climate in post-genocide Rwanda: most notably, that Rwandans continue to see their nation's past through vastly different lenses, demonstrating the enormous challenges facing the Rwandan government as it seeks to reconcile its population using current methods. It also highlights the ongoing need on the part of historians to approach contemporary sources critically, informed by sources produced and debated in the pre-genocide period.
\end{abstract}


Bio-sketch: Erin Jessee is a Lecturer with the Scottish Oral History Centre at the University of Strathclyde. She has a PhD in the Humanities from Concordia University. Her current book project, tentatively titled Negotiating Genocide: The Politics of History in Post-Genocide Rwanda, examines how Rwandan survivors, génocidaires, government officials, and bystanders invoke history to make sense of their postgenocide lives. Contact: erin.jessee@strath.ac.uk Sarah E. Watkins is a doctoral candidate in History and Feminist Studies at the University of California, Santa Barbara. Her dissertation explores gendered dynamics of monarchical power in Rwanda. Contact: sarah.e.watkins@gmail.com

\section{Introduction $^{1}$}

The Rwandan monarchy has long been a subject of interest for Rwandan historians, and foreign missionaries and scholars, as indicated by the plethora of sources on the subject available in Kinyarwanda, French, and English. In most instances, studies of the Rwandan monarchy draw upon contemporary oral historical and archival sources to inform an understanding of how Rwandans in the past related to the monarchy and vice versa. Conversely, this article \#\# a collaboration between two researchers who worked on separate projects in Rwanda between 2007 and 2013 \#\# draws upon oral historical and archival sources to analyze how modern Rwandans

\footnotetext{
${ }^{1}$ The authors wish to thank their Rwandan research assistants and participants. We are also grateful to Stephan Miescher, Rose-Marie Mukarutabana and two anonymous reviewers for providing valuable feedback on earlier drafts of this paper. The preparation and writing of this article was funded by the Social Sciences and Humanities Research Council of Canada; the Association of Universities and Colleges of Canada and the Canadian International Development Agency's Students for Development Internship; the American Historical Association; and the Graduate Division and Department of History at the University of California, Santa Barbara.
} 
internalize and evoke a range of social, political and personal factors in their representations of the monarchy, and specific monarchical figures, in the everyday.

We begin by introducing the concept of "mythico-history" as an appropriate framework for making sense of divergent narratives in post-genocide Rwanda. ${ }^{2}$ Next, we discuss the methodological foundation that informs current historical knowledge of the Rwandan monarchy, with particular emphasis placed on relevant oral historical and archival sources as interpreted by historians. We then present three mythico-histories related to the Rwandan monarchy as voiced by Rwandans from different social, ethnic, and political backgrounds. In each instance, analysis reveals that these mythico-histories encode the narrator's relationship to the current official narrative promoted by the Rwandan Patriotic Front (RPF) led by President Paul Kagame, and to a lesser extent, the official narratives promoted by the pregenocide regimes of Presidents Grégoire Kayibanda (1962\#\#1973) and Juvénal Habyarimana (1973\#\#1994). In doing so, we demonstrate the ongoing tensions plaguing post-genocide Rwanda related to the politics of history and memory and the everyday challenges negotiated by Rwandans.

\section{Post-Genocide Narratives as Mythico-Histories}

The theoretical framework informing this article was first articulated by Liisa Malkki, whose work among Hutu refugees of the 1972 Burundian genocide led her to identify a range of "mythico-histories" that her participants used to make sense of their pre- and post-genocide lives. Malkki defines the mythico-history as "not only a description of the past, not even merely an evaluation of the past, but a subversive

\footnotetext{
${ }^{2}$ Liisa Malkki, Purity and Exile: Violence, Memory and National Cosmology Among Hutu Refugees in Tanzania (Chicago: Chicago University Press, 1995).
} 
recasting and reinterpretation of it in fundamentally moral terms."3 Her participants, who decades later were still living in refugee camps in Tanzania, had developed an extreme form of Hutu nationalism that depicted the Tutsi as foreigners who had, through trickery and deceit, stolen the nation from its "rightful natives." ${ }^{4}$ To this end, her participants used a series of mythico-histories to frame their displacement "in opposition to other versions of what was ostensibly the same world, or the same past"- that of the Burundian Tutsi elites. ${ }^{5}$ In doing so, they reordered their social and political world through stories that, while questionable in terms of their historical accuracy, nonetheless were psychologically true for the individuals who narrated them.

Using the mythico-history framework to approach narratives in post-genocide Rwanda \#\#as well as other nations in the Great Lakes of Africa region \#\# is wellestablished. ${ }^{6}$ Of particular relevance to this article, Jennie Burnet has recently cast the RPF's ongoing program of nationalized commemoration surrounding the 1994

${ }^{3}$ Malkki, Purity and Exile, 54.

${ }^{4}$ Malkki, Purity and Exile, 3.

${ }^{5}$ Malkki, Purity and Exile, 55.

${ }^{6}$ For example, Marc Sommers' review of Malkki's work notes the mythico-history's relevance for Central Africa and that experts like René Lemarchand are applying the concept to their own work. In addition, Elizabeth King has adapted the mythico-history to frame memories of Hutu discrimination that were related by her Rwandan participants, but which were adapted from the lived experiences of their grandparents and parents, while Yolande Bouka has applied it to the RPF's official narrative surrounding the 1994 genocide and First Congo War. For more information, see Marc Sommers, "Review of Liisa Malkki, Purity and Exile: Violence, Memory, and National Cosmology Among Hutu Refugees in Tazania," American Anthropologist 99\#\#1 (1997), 218; Elizabeth King, "From Data Problems to Data Points: Challenges and Opportunities of Research in Postgenocide Rwanda," African Studies Review 52\#\#3 (2009), 127\#\#148; Yolande Bouka, "(Oral) History of Violence: Conflicting Narratives in Post-Genocide Rwanda," Oral History Forum d'Histoire Orale 33 (2013), 7. 
genocide as an example of mythico-history in action. She offered two examples of the RPF mythico-history: the use of the international community's failure to intervene to prevent the genocide as a political weapon against international criticisms of the Rwandan government; and the invoking of injured bodies of the living and the dead victims of genocide as evidence of the genocide, the international community's complicity, and the necessity of RPF leadership for preventing further bloodshed. ${ }^{7}$

The concept of the mythico-history in action is similarly apt to apply to modern narratives of the Rwandan monarchy. Rwanda's public sphere, as evidenced by a plethora of government-funded museum exhibits, genocide memorials, transitional justice mechanisms and educational materials aimed at educating the public and promoting national unity and reconciliation, is dominated by an image of Rwanda's precolonial past as relatively utopian: its people united under a monarchy that, for the most part, was successful at maintaining peace and stability in the region. As part of this official narrative, Hutu, Tutsi, and Twa ethnic identities were introduced by the German and Belgian colonizers in the early twentieth century, setting Rwanda on an irreversible path toward the 1994 genocide, in which an estimated one million Tutsi were brutally murdered. ${ }^{8}$ However, as the following discussion reveals, the subject of the Rwandan monarchy is fraught with historiographic debate, and its interpretation by modern Rwandans far more complicated than indicated by the RPF's official history.

${ }^{7}$ Jennie Burnet, "Whose Genocide? Whose Truth? Representations of Victim and Perpetrator in Rwanda," in: Alexander Hinton and Kevin O’Neill (eds.), Genocide: Truth, Memory, and Representation (Durham: Duke University Press, 2009), ADD PAGE NUMBERS CHAPTER 96.

${ }^{8}$ Sources from outside Rwanda cite the actual number of victims of the 1994 genocide at between 500,000 to 800,000 Rwandans, including Tutsi, Hutu, and Twa civilians. See, for example: Alison Des Forges, Leave None to Tell the Story: Genocide in Rwanda (New York: Human Rights Watch, 1999). 


\section{Oral/Archival Sources on the Rwandan Monarchy}

Much of what is known about the Rwandan monarchy and its impact on the everyday lives of Rwandans emerges from the work of historians, most notably Alexis Kagame, Jan Vansina, and David Newbury, whose analysis relies upon engagement with rich oral sources. There are four main types of oral sources with which historians work: ubwiru (rituals), ubucurabwenge (dynastic lists), ibisigo (dynastic poetry), and ibitéekerezo (historical narratives). The ubwiru are in some ways the most famous of these, but also the most secret. They were memorized by the abiru (ritual practitioners), a group that acted both as priests \#\# performing the rituals \#\# as well as a council of advisors to the mwami (king), who was the chief ritual practitioner in the kingdom. ${ }^{9}$ Court genealogists, the abacurabwenge, kept the dynastic lists. The ibisigo, or dynastic poetry, was kept by the abasizi, who belonged mostly to the Singa clan. Alexis Kagame belonged to the Singa clan, and recorded these traditions. This gave him access to King Rudahigwa, and to the abiru. ${ }^{10}$ It is clear he did extensive

${ }^{9}$ These rituals were compiled and analyzed as they were performed during the colonial period. See: André Coupez and Marcel d'Hertefelt, La Royauté Sacrée de l'Ancien Rwanda: Texte, Traduction et Commentaire de son Rituel, (Tervuren: Musée Royal de l'Afrique Centrale, 1964); David Newbury's analysis of the "First Fruits" ritual is important for understanding how these rituals helped to construct community and identity. See: David S. Newbury, "What Role Has Kingship?: An Analysis of the Umuganura Ritual of Rwanda as Presented in Marcel d'Hertefelt and Andre Coupez La Royaute Sacree de l'Ancien Rwanda (1964)," Africa-Tervuren 27\#\#4 (1981), 89\#\#101.

${ }^{10}$ As a matridynastic clan, it is unlikely that the Singa were actually part of the abiru. Rwandan scholar Rose-Marie Mukarutabana argues that the Singa had a "quasi-monopoly" over the ibisigo, dynastic poetry. Personal communication WITH JESSEE OR WEATKINS??, January 2014. Meanwhile, the incorporation of the abiru at the royal? court seems to date from the reign of Gisanura, which Vansina places sometime between 1700 and 1735. The genealogy and dating of the Nyginya dynasty has been a matter of much discussion among historians of Rwanda. See: Léon Delmas, Généalogies de la Noblesse du Ruanda (Les Batutsi), (Kabgayi: Vicariat apostolique du Ruanda, 1950); Alexis Kagame, La notion de génération appliquée à la généalogie dynastique et à l'histoire du Rwanda 
interviews and perhaps took careful fieldnotes as well. ${ }^{11}$ But he never revealed the identities of his informants, nor did he explain their backgrounds. ${ }^{12}$ They may have included ibitéekerezo, or ubwiru. It is likely, though, that he relied mostly upon ibisigo. ${ }^{13}$ This makes a critical analysis of Kagame's work challenging, since it is difficult to know the type of source and from whom it was obtained except in those instances in which Kagame directly attributes information to particular informants.

In comparison, Jan Vansina's work is predominantly based on ibitéekerezo. ${ }^{14}$ Though these were also somewhat controlled by the court, they also disseminated

des Xe-XIe siècles à nos jours, par l'abbé Alexis Kagame (Bruxelles: PUBLISHER ?, 1959); Bernardin Muzungu, Histoire du Rwanda Précolonial, (Paris: L’Harmattan, 2003); David S. Newbury, “Trick Cyclists? Reconceptualizing Rwandan Dynastic Chronology," History in Africa 21 (1994), 191\#\#217; J.K. FULL NAME AVAILABLE ?? Rennie, “The Precolonial Kingdom of Rwanda: A Reinterpretation," Transafrican Journal of History 2\#\#2 (1972), ADD PAGE NUMBERS; Jan Vansina, L'Évolution du Royaume Rwanda des Origines $\square \square 1900$ (Bruxelles: Acade $\square$ mie Royale des Sciences d'Outre-Mer, 2000). For more on the incorporation of the abiru into the Nyiginya Kingdom, see: David S. Newbury, "What Role Has Kingship?;” Vansina, Antecedents to Modern Rwanda: The Nyiginya Kingdom (Madison: University of Wisconsin Press, 2004), especially Chapter 4.

${ }^{11}$ These notes are reportedly held in the Abbé Alexis Kagame Library in Butare. As of November 2012, they were unavailable to researchers, whether Rwandan or foreign.

${ }^{12}$ Jan Vansina, "Historical Tales,” History in Africa 27 (2000), 375\#\#414.

${ }^{13}$ For more on the differences between oral sources and their interpretations, see: Coupez and d'Hertefelt, La Royauté Sacrée; Vansina, "Historical Tales.” For some examples and theories on Kagame's sources, see: Alexis Kagame and Pierre Charles, La Poésie Dynastique au Rwanda, par Alexis Kagame (Bruxelles: G. van Campenhout, 1951); Alexis Kagame and Gérard Nyilimanzi, Ibisigo comme source de l'histoire (Kigali: Cahiers Lumiere et Societé, 2003).

${ }^{14}$ Vansina contrasts his ibitéekerezo with what he refers to as "official histories" offered by courtbased collaborators of Peter Schumacher, who worked in Rwanda IN WHICH DECADE?. See: Vansina, Antecedents, 7\#\#8; Jan Vansina, L’Évolution. For Schumacher, see: Kayijuka, “Lebensgeschichte des Grossfürsten Kayijuka und Seiner Ahnen Seit Sultan Yuhi Mazimpaka, König von Ruanda. Von Ihm Selbst Erzählt. Translated by Dr. Peter Schumacher, M.A.,” 
throughout the population, since non-elites also worked at the court. ${ }^{15}$ Thus there were both official ibitéekerezo, as well as popular versions that included personal and regional embellishments. In some ways, Vansina's work built upon Kagame's. ${ }^{16}$ But he challenged Kagame's chronology, for example, as well as his interpretation of the older, mythological narratives. Vansina also included regional and local narratives in his collection of ibitéekerezo, which helps to contextualize his monarchical history beyond the add: royal? court narratives. ${ }^{17}$

David Newbury's contribution has been to place the Rwandan monarchy within a regional context and to further critique Kagame's presentation of an official dynastic history of the Nyiginya monarchy as a national Rwandan history. Newbury argues that the monarchy was an example of ritual kingship. ${ }^{18}$ The mwami was not a god, but rather the earthly conduit through which spiritual blessings flowed into the kingdom. ${ }^{19}$ He was bound by a cyclical series of rituals performed in various parts of

Mitteilungen der Ausland-Hochschule an der Universität Berlin 41 (Afrikanischen Studien) (1938), 103\#\#161.

${ }^{15}$ The most famous of these is the tanner Gakanisha, who was the sole information for Coupez and Kamanzi’s book of ibitéekerezo. See: André Coupez, Th. Kamanzi and Clément Gakanísha, Recits Historiques Rwanda (Tervuren: Musée Royal de l'Afrique Centrale, 1962). This was also likely the type of story that informed Peter Schumacher's famous narrator Kayijuka, several decades prior to Coupez and Kamanzi. Kayijuka. "Lebensgeschichte," (1938).

${ }^{16}$ See Vansina, Antecedents, in which Kagame's work is among the most frequently cited sources.

${ }^{17}$ Vansina, "Historical Tales;" Vansina, Antecedents.

${ }^{18}$ David S. Newbury, Kings and Clans: Ijwi Island and the Lake Kivu Rift, 1780-1840 (Madison WI: University of Wisconsin Press, 1991). See also: D. Newbury, "What Role Has Kingship?” ${ }^{19}$ This interpretation may seem confusing FOR CHRISTIANS? in a modern-day context, depending on one's theological interpretation of the Christian Trinity and the role of Jesus Christ therein. I DON'T SEE THIS POINT. TO ME, IT HAS NOT ANYTHING TO DO WITH CHRISTIANITY. EXPLAIN, PLEASE. However, the pre-colonial conception of the mwami was that of the chief ritual practitioner, and one who existed between the mortal inhabitants 
the country to ensure prosperity and fertility, his body being an essential part of these rituals, up to and including burial. ${ }^{20}$ Newbury widens the analysis of political development to place Rwanda within the context of its region, including what is now eastern Democratic Republic of Congo, and especially Ijwi Island, which lies in Lake Kivu.

Archival sources on Rwanda become relevant from 1897 when Germany claimed Rwanda as part of German East Africa. However, the German government expended few resources in its colonial holding, and did not endeavor to change preexisting social or political structures. Instead, they lent support to one side of a succession dispute that began in 1895 with the death of Rwabugiri by giving military resources to Musinga, who ascended the throne in $1896 .{ }^{21}$ It is unlikely that Musinga could have held the throne without German support, but a few months after his accession, von Ramsay, a German officer, appeared at court and proposed an alliance between the king and the colonial authorities that Musinga's mother,

of Rwanda and Imaana, the supernatural heavens. See, for example: Kagame and Charles, La Poésie Dynastique, particularly no. 65, no. 66, and no. 67.

${ }^{20}$ Coupez and d'Hertefelt's collection of the rituals is most important here, but other have also offered interpretation and analysis of the cyclical nature of the royal rituals and their importance in the cosmological structure of the Nyiginya kingdom. See: Coupez and d'Hertefelt, La royaute sacrée; D. Newbury, “What Role Has Kingship?:” Vansina, Antecedents, especially 91\#\#93. Christopher Taylor has also written extensively about the symbolic capital surrounding the king's body in precolonial and colonial Rwanda rituals. See: Christopher Taylor, Sacrifice as Terror: The Rwandan Genocide of 1994 (Oxford: Berg Publishers, 1999); Christopher Taylor, Milk, Honey and Money: Changing Concepts in Rwandan Healing (Washington: Smithsonian Institution Press, 1992).

${ }^{21}$ Vansina, Antecedents, 2004. The coup that resulted in Musinga's enthronement is often remembered as one of the bloodiest events in Rwanda history up until the genocide. See also: Alison Des Forges, Defeat is the Only Bad News: Rwanda Under Musinga, 1896\#\#1931 (Madison: University of Wisconsin Press, 2011). For an example of a popular remembrance, see: E.FULL NAME KNOWN? Ruhashya, Rucunshu ([Kigali?]: Imprimerie nationale du Rwanda, 1984). 
Kanjogera, immediately accepted. ${ }^{22}$ In placing her own son on the throne, she solidified her Abakagara lineage of the Ega clan as the most powerful in the kingdom, eclipsing in a variety of ways the power of the reigning Nyiginya. ${ }^{23}$ Thus began Rwanda’s colonial era.

German colonization was short-lived. During World War I, the Belgians took control of the colony, soon to be joined with Burundi and renamed Ruanda-Urundi. Unlike their colonial predecessors, the Belgians were determined to homogenize what had previously been a small, central kingdom that controlled the surrounding communities through assimilation and military force, and which was a diverse territory in terms of identity and power. ${ }^{24}$ The Belgian administration was buffered by pseudoscientific theories that identified the Tutsi minority to be descendants of the biblical figure Ham, and therefore more "Caucasian" than their pure African Hutu and Twa compatriots. It concluded that the Tutsi were more intelligent and that a Tutsi-dominated social hierarchy was therefore natural. ${ }^{25}$ In doing so, they

${ }^{22}$ Des Forges, Defeat is the Only Bad News.

${ }^{23}$ Kanjogera was already queen-mother (umugabekaz?) for the previous mwami, Rutarindwa, who was not her biological son. It was not enough for her to simply be umugabekari; rather, as a descendant of the powerful Abakagara lineage of the Ega clan, her ambitions included strengthening her family's position as well, which is why she participated in the coup that overthrew Rutarindwa in 1896 and established her own son as mwami. In this way, she was very much the ideological heir of her father, Rwakagara, as well as his sister and her own predecessor as queen-mother, Nyiramongi. See: Sarah E. Watkins, "Iron Mothers and Warrior Lovers: Intimacy, Power, and the State in Rwanda, 1796\#\#1912," PhD Dissertation, Santa Barbara (University of California, 2014), especially Chapter 4.

${ }^{24}$ Catharine Newbury, The Cohesion of Oppression: Clientship and Ethnicity in Rwanda, $1860 \# \# 1960$ (New York: Columbia University Press, 1988).

${ }^{25}$ For an excellent analysis which highlights the missionary origins of the Hamitic Hypothesis, see Edith R. Sanders, "The Hamitic Hypothesis: Its Origin and Functions in Time Perspective," Journal of African History 10\#\#4 (1969), 521\#\#532. 
eliminated all available avenues to power for Hutu, including streamlining chieftainship into a single hierarchy that governed agriculture, pastoralism, and the army, and removing all existing Hutu chiefs. ${ }^{26}$

The period after the Second World War brought new realities for European colonial powers, and the newly-formed United Nations renewed Belgium's administration of Rwanda as a Trust Territory. Under this mandate, the Belgians were tasked with preparing Rwanda for eventual independence. This created many factions within the country, mostly splitting along ethnic lines. The situation grew more tense throughout the 1950s, and the sudden and rather mysterious death of the mwami Rudahigwa in 1959 set off a series of violent conflicts around the country. The Belgians, anxious to relieve themselves of the burden of their small Trust Territory, and distracted by events in neighboring Congo, implemented a final series of elections.

This was the first opportunity since the pre-colonial period that Hutu had to lead the nation. Despite reports to the United Nations Visiting Mission by the Belgian administration and complaints among Tutsi parties that this model for governance was ineffective, the Hutu parties won $83.84 \%$ of the vote during the 1960 election for communal representation. ${ }^{27}$ These elections established the Rwanda Provisional Government, which took control of internal governance of the country as of 25 January 1961. Full independence from Belgium was then achieved under almost exclusively Hutu leadership on 1 July 1962. The period from 1959 to 1962 was marked by widespread anti-Tutsi violence, and many Tutsi fled to neighboring countries or even Europe or North America. Subsequent waves of Tutsi

\footnotetext{
${ }^{26}$ Belgian Congo and Ruanda-Urundi Information and Public Relations Office, Ruanda-Urundi: Geography and History (TOWN? PUBLISHER? 1960), 72. See also Taylor's discussion of the Hamitic hypothesis in Sacrifice as Terror.

${ }^{27}$ Mary Catherine Atterbury, "Revolution in Rwanda" (Madison WI: African Studies Program \#\# University of Wisconsin, 1970), 76.
} 
exiles would follow related periods of political tension and violence in 1963 and 1964, and again in 1973 surrounding Habyarimana's rise to power, though Habyarimana himself condemned this violence and worked to protect Tutsi who remained in Rwanda. Cumulatively, these Tutsi are often referred to as "old-caseload refugees" to differentiate them from refugees who fled the 1994 genocide and subsequent conquest by the RPF, though each wave of refugees took on its own unique character. The timing of each group's flight was determined by distinct circumstances, often unique to political turmoil in particular parts of the country. This, too, impacted where specific Tutsi groups chose to flee and to resettle. ${ }^{28}$

\section{On Methodology}

The methodological framework underlying this paper relies primarily upon life history and thematic interviews with over one hundred Rwandans from a range of social, political, economic, ethnic, and regional backgrounds. ${ }^{29}$ In incorporating interviews into our fieldwork, we were following Lynn Abrams and other oral historians who approach oral history as both a research methodology and an end result that are distinct from the use of oral sources in other disciplinary settings. ${ }^{30} \mathrm{~A}$ budding sub-discipline that bridges a range of social scientists and community-based practitioners, oral historians rely primarily on the collection, analysis and dissemination of life history and thematic interviews as a means of engaging with

\footnotetext{
${ }^{28}$ See Jean-Pierre Chrétien, The Great Lakes of Africa: Two Thousand Years of History (New York: Zone Books, 2003); Rene Lemarchand, Rwanda and Burundi (New York: Praeger Publishers, 1970); C. Newbury, The Cohesion of Oppression; Filip Reyntjens, Pouvoir et Droit au Rwanda: Droit Public Et Evolution Politique, 1916\#\#1973 (Tervuren: Muse $\square$ e Royal de l'Afrique Centrale, 1985).

${ }^{29}$ Pseudonyms are used throughout this article in order to maintain the confidentiality of our participants. In addition, we refrain from including personally identifying information.

${ }^{30}$ Lynn Abrams, Oral History Theory (New York: Routledge, 2010).
} 
those versions of the past that are largely absent from official sources of historical knowledge, resulting in an intimate "view from below." To this end, Rwandan participants were recruited by seeking out both professional historians and "organic intellectuals" \#\# community-recognized leaders with expertise in local histories, storytelling and culture, rather than government-approved experts \#\# in a range of settings, as well as ordinary civilians who felt they had a story to tell. ${ }^{31}$ We then sought out additional participants by asking participants to recommend people from their communities who could enhance our understanding of Rwandan history, or a particular event. All consenting participants were interviewed, including government officials, to allow for a more nuanced understanding of Rwandan history.

After establishing informed consent with our participants, we conducted life history interviews. In these initial interviews, participants were encouraged to narrate their life experiences in as little or as much detail as was necessary for us to understand how their past and present circumstances might influence their narratives. As such, we asked few questions, instead preferring to have our participants tell us about themselves and their experiences on their own terms and touch on those events that they felt were most important to them, rather than our research agendas.

Once participants concluded that their life stories had been narrated in sufficient detail, subsequent conversations took the form of thematic interviews in

\footnotetext{
${ }^{31}$ This group was incredibly diverse. In some cases, these were university-trained historians who had done community-based work. Others were singers and storytellers whose knowledge and ability to communicate histories made them prominent members of communities, including those in various diasporas. The last category included rural and poor urban residents, often semi-literate or illiterate, who were considered as important sources of historical information and analysis by others on their hill or in their neighbourhood. For further analysis of a similar case to this last group, see: Steven Feierman, Peasant Intellectuals: Anthropology and History in Tanzania (Madison WI: University of Wisconsin Press, 1990).
} 
which we asked questions tailored to our participants' backgrounds while simultaneously addressing our particular research interests. By the end of our fieldwork, we had conducted as many as six formal interviews with each participant. This approach was influenced by Henry Greenspan, whose decades of work among Holocaust survivors now living in the United States highlights the value of oral sources, particularly when the practitioner is able to revisit the survivors' experiences several times over a period of weeks, months, or even years. ${ }^{32}$

Greenspan advocates conducting multiple interviews with each individual so that over time the listener comes to understand the greater historical, political, cultural and social contexts that influence an individual's interpretations of their experiences over time. This approach simultaneously allows the listener to engage in two central tenets of oral historical practice. First, it encourages "deep listening," whereby the researcher seeks to engage not only with the words being uttered, but with the deeper meaning inherent in the narrative as a whole. ${ }^{33}$ Second, it enables

\footnotetext{
${ }^{32}$ The use of Greenspan in this instance is not intended to imply that the authors believe that insights based on the Holocaust are automatically relevant to Rwanda due to a shared experience of genocide. Instead, it is intended to demonstrate that the use of life history interviews, and indeed, the strategy of conducting multiple interviews with a single participant over a period of time can greatly enhance our understanding of the political and social forces that shape how people narrate their lived experiences.

${ }^{33}$ For more on deep listening, see: Alessandro Portelli, They Say in Harlan County: An Oral History (New York: Oxford University Press, 2010); Alessandro Portelli, "What Makes Oral History Different," in: Robert Perks and Alistair Thomson (eds.), The Oral History Reader, Second Edition (New York: Routledge, 2006), 32\#\#42; Alessandro Portelli, The Order Has Been Carried Out: History, Memory, and Meaning of a Nari Massacre in Rome (New York: Palgrave MacMillan, 2003); Alessandro Portelli, The Death of Luigi Trastulli and Other Stories: Form and Meaning in Oral History (New York: State University of New York Press, 1991); Paul Thompson, "The Voice of the Past: Oral History," in: Robert Perks and Alistair Thomson (eds.), The Oral History Reader, Second Edition (New York: Routledge, 2006), 25\#\#31; Paul Thompson, The Voice of the Past: Oral History (Oxford:
} 
practitioners to share authority with their participants to establish a common understanding of events. ${ }^{34}$ In doing so, it engages with and builds upon crucial dialogue initiated by Africanist historians in the 1990s, which prompted practitioners to speak with, rather than for, their African interlocutors, and to acknowledge the different reliability of African oral histories and traditions, as complimentary to other ways of knowing about the continent's history. ${ }^{35}$

To these insights, we would add that the resulting testimonies may speak volumes about not only what the listener anticipates hearing, but also about what Rwandans anticipate local authorities might want to hear, should the contents of the interviews ever become public knowledge. This expansion of Greenspan's approach acknowledges that many Rwandans find themselves torn between narrating their lived experiences on one hand, and remaining faithful to the RPF's official narrative of Rwanda's past and present on the other, lest they be identified within the community as potential political dissidents. ${ }^{36}$

Oxford University Press, 1988); Luisa Passerini, Fascism in Popular Memory: The Cultural Experiences of the Turin Working-Class (Cambridge: Cambridge University Press, 1987).

${ }^{34}$ For more on sharing authority, see: Michael Frisch, A Shared Authority: Essays on the Craft and Meaning of Oral and Public History (Albany: State University of New York Press, 1990); Steven High, "Sharing Authority: An Introduction," Journal of Canadian Studies 43\#\#1 (2009), 12\#\#34; Steven High, Lisa Ndejuru and Kristen O’Hare (eds.), "Special Issues on Sharing Authority: CommunityUniversity Collaboration in Oral History, Digital Storytelling, and Engaged Scholarship," Journal of Canadian Studies 43\#\#1 (2009), PLEASE ADD PAGE NUMBERS.

${ }^{35}$ See, for example: David W. Cohen, Stephan F. Miescher and Luise White, "Introduction: Voices, Words, and African History" in: Luise White, Stephan F. Miescher and David W. Cohen (eds.), African Words, African Voices: Critical Practices in Oral History (Bloomington: Indiana University Press, 2001), 1\#\#30.

${ }^{36}$ For more on the methodological challenges and limitations of conducting oral historical research in post-genocide Rwanda, and when working with narratives that are politically sensitive, see: Erin Jessee, "The Limits of Oral History: Ethics and Methodological Amid Highly Politicized Research 
In instances where formal recorded interviews were not possible, the empirical evidence underlying this paper is enhanced by ethnography, which Karen O’Reilly defines as

a family of methods, involving direct and sustained contact with human agents within the context of their daily lives (and cultures), watching what happens, listening to what is said, and asking questions. (...) It results in richly written accounts that respect the irreducibility of human experience (...) acknowledges the role of theory $(\ldots)$ as well as the researcher's own role $(. .$.$) and views$ human as part object / part subject. ${ }^{37}$

To this end, the authors have been periodically immersed in everyday life in postgenocide Rwanda and have engaged in a range of ethnographic methods aimed at documenting and analyzing informal encounters and the nation's rapidly shifting political climate. Jennie Burnet's discussion of intersubjectivity \#\# in her study "the dialogue and interactions between the anthropologist, her research topic, and her research participants as well as between the conflicting points of view of her research participants" \#\# is particularly salient. ${ }^{38}$ Intersubjectivity emerges from a

Settings," Oral History Review 38\#\#2 (2011), 287\#\#307; Marc Sommers, Stuck: Rwandan Youth and the Struggle for Adulthood (Athens GA: University of Georgia Press, 2012); Susan Thomson, Whispering Truth to Power: Everyday Resistance to Reconciliation in Postgenocide Rwanda (Madison WI: University of Wisconsin Press, 2013).

${ }^{37}$ Karen O'Reilly, Key Concepts in Ethnography (London: Sage Publications, 2009), 3 \#\# emphasis in original.

${ }^{38}$ Jennie Burnet, Genocide Lives in Us: Women, Memory, and Silence in Rwanda (Madison WI: University of Wisconsin Press, 2012), 35 \#\# her discussion on intersubjectivity builds upon work by Pierre Bourdieu and James Clifford. 
combination of self-reflection on the part of the researcher, daily immersive interactions with participants, and the contrasting of different voices and perspectives as part of the final analysis. This requires the ethnographer to consider his/her own subjectivity: past experiences, and relationships with participants, disciplinary background(s), research questions, and the case study intended to investigate. This is typically accomplished through the writing of fieldnotes \#\# a process that involves thorough documentation of field experiences in as much detail as humanly possible, while simultaneously reflecting on how each encounter potentially shifts the course taken by the research project. ${ }^{39}$ The subsequent analysis is a messy process involving sorting and coding the resulting data \#\# including photographs, fieldnotes, audio and video recordings, and more \#\# and identifying key themes or contradictions that respond to the guiding research questions and advance critical theory.

The resulting fieldwork has been necessarily multi-sited. ${ }^{40}$ During different fieldwork trips, the authors have been based in Kigali (the national capital), Butare (Rwanda's cultural center), and Kibuye (a town in western Rwanda). In addition, we made numerous trips beyond these more accessible communities to engage with the experiences and perspectives of Rwandans from rural communities, allowing for a more diverse range of economic, regional, and political backgrounds among our participants. For this reason, our approach necessitated certain compromises. We were rarely able to immerse ourselves in the daily lives of our participants, in part due to our decision to travel within the country to reach a wider range of experiences, and also in part because of our commitment to researching Rwandan

\footnotetext{
${ }^{39}$ Julian Murchison, Ethnography Essentials: Designing, Conducting, and Presenting Your Research (San Francisco: Jossey-Bass, 2010).

${ }^{40}$ For more information on multi-sited ethnography, see: Ulf Hannerz, "Being There... and There... and There! Reflections on Multi-Site Ethnography," Ethnography 4\#\#2 (2003), $201 \# \# 216$.
} 
communities where the prolonged presence of a foreign researcher could provoke unwanted attention from the Rwandan government and endanger participants. And in the neighborhoods where we lived, our inability to speak fluent Kinyarwanda impeded our ability to communicate directly with our neighbors, who spoke little English. French was an option; however, the French language has become increasingly unpopular among Rwandans due to the RPF's decision to adopt English as its second language. ${ }^{41}$ As a result, we worked closely with Rwandan research assistants who provided simultaneous translation during interviews and transcription of recorded interviews from Kinyarwanda to English.

\section{Mythico-History 1: The Good King}

One of many diasporic communities that have fled Rwanda in recent years are the old case-load refugees who fled anti-Tutsi violence in waves from the $1959 \mathrm{Hutu}$ Revolution to Habyarimana's 1973 coup. These refugees often maintained intimate ties to the monarchy. ${ }^{42}$ For them, the monarchy is often a source of honor, and the memory of it evokes strong feelings of kinship, nostalgia and integrity, particularly in relation to the heightened ethnic tensions and economic decline of the Kayibanda and Habyarimana regimes. Among this community, the story of The Good King \#\# a colonial-era confrontation at Hotel Faucon \#\# circulates as evidence of the benevolent and ultimately superior leadership of Tutsi monarchy. A Rwandan

\footnotetext{
${ }^{41}$ In Kigali in particular, many Rwandans do not want to be seen speaking French, as doing so affiliates them with the francophone regimes of Habyarimana and Kayibanda and places them in a precarious political position. Cf. Izebela Steflja, "The Costs and Consequences of Rwanda's Shift in Language Policy," African Portal 30 (2012), 1\#\#10 (http://www.africaportal.org/articles/2012/05/31/costs-and-consequencesrwanda $\%$ E2\%80\%99s-shift-language-policy, accessed 6 June 2013).

${ }^{42}$ See also: Burnet, Genocide Lives in Us, 15.
} 
historian, herself an old case-load refugee who has since YEAR MISSING? returned to Rwanda, narrated the event as follows to one of us:

Hotel Faucon was owned by a Belgian settler called Faucon, who had placed a sign at the entrance, reading "Interdit aux chiens et au noirs." When King Mutara Rudahigwa saw the sign, he strode over and removed it himself. When the owner came out and began to protest, the king slapped him and threatened him with worse if he did not stop this insulting nonsense. The king had been stopping at the hotel, and the sign had not been meant to exclude him. But he could not accept segregation against anyone at all. From that day, segregation in public spaces ended throughout the country.

When asked if the monarchy had been good for Rwanda, this incident was often cited by returnees as an example of why it was, and why, according to two interviewees, most Rwandans had voted to maintain the monarchy in the 1962 referendum. This interpretation is, of course, challenged by historical facts: the monarchists were defeated in the referendum, and a republican system was established to replace Belgian colonial administration. Further, the abolition of the monarchy was functionally achieved after the 1960 elections of mayors ("bourgmestres" in the Belgian system) and local council members. These newlyelected officials \#\# who were majority Hutu, reflecting the reality of the country \#\# were escorted by the Belgians to a safe meeting place in Gitarama on 28 January 1961. Here, the elected representatives proclaimed the Republic. Due to opposition to this so-called "Coup of Gitarama" by the United Nations (under whose aegis Belgium administered Rwanda as a Trust Territory), a referendum was held in 1962 that formally ended the monarchy. But Kigeli V Ndahindurwa fled to Tanganyika following the Coup of Gitarama, essentially ending Rwanda's monarchy. 
Nonetheless, the myth that the monarchists won, prompting the Belgians to tamper with the election results, persists among to the narratives of many old-caseload returnees despite these historical events.

The collective historical memory of diaspora populations presents a unique challenge for historians. Liisa Malkki argues that refugees have been represented in the scholarly literature as "stripped of the specificity of culture, place, and history, [the refugee] is human in the most basic, elementary sense. The refugee as bare humanity stands, we imagine, for all of us at our most naked and basic level." ${ }^{\text {43 }}$ But as Malkki's research shows, refugees are not the tabula rasa of humanity \#\# they are people who lived in a specific context, left for specific reasons, and now live within another context. They are aware of their surroundings and historical moment. Most importantly, Malkki reveals that refugees exercise agency by constructing their own narratives and identities within their new context. This final point is of utmost importance for understanding narratives of The Good King.

Rwandan Tutsi, and particularly those closely affiliated within the monarchy, were understandably afraid for their safety surrounding the Hutu Revolution. The Belgians were distracted by ongoing violence in the neighboring Congo, where they had larger economic and strategic interests, and regardless, were unlikely to spend very much time worrying about backlash against Rwanda's royal family and its supporters. Members of the royal family fled to Burundi, Kenya, Tanzania, and Uganda. Many hoped they would soon be able to return.

A "princess" of Musinga's clan turned prominent storyteller had much to say about this narrative of The Good King. She grew up in a small village in central Rwanda and was quick to dismiss perceptions that she had enjoyed the privileges of the royal court as a girl. She instead emphasized the humble life her family had led as farmers and small-scale pastoralists. She claimed that Musinga probably "did not

\footnotetext{
${ }^{43}$ Malkki, Purity and Exile, 12 \#\# emphasis in the original.
} 
know her name." Yet despite this humble life, she was privately educated \#\# a privilege, especially for girls, during the colonial period \#\# and received her university education at the National University of Rwanda. Furthermore, among old case-load refugees, she was commonly recognized as The Princess, DOESN'T

THIS BRING HER ANONYMITY IN DANGER? demonstrating a lingering respect for her heritage.

When Rudahigwa died in 1959, The Princess married a civil servant in the colonial regime. Concerned for his family's safety, her husband sent her to Bujumbura to wait until the violence subsided, but eventually it became clear that return was not a safe option. For Tutsi who stayed in Rwanda after 1962, life was perilous. The Kayibanda regime systematically removed Tutsi from positions of power, creating a general atmosphere of anti-Tutsi discrimination. When Habyarimana overthrew the Kayibanda regime in 1973, more Tutsi fled, fearing further backlash within their communities. At this point, The Princess's husband joined her in Bujumbura. They lived in exile until 1996, when the relative stability of the RPF regime made it possible for them to return to Rwanda.

As exiles, many old case-load refugees began sharing stories. In Bujumbura, The Princess gained a following, earning a reputation as a guardian of Rwandan history and culture. A popular belief, likely bolstered by The Princess's storytelling, was that the Belgian administrators had falsified the results of the referendum, and that Rwandans had actually voted overwhelmingly to preserve the monarchy. Conversations with her, as well as other former exiles from Bujumbura, Nairobi, and Dar es Salaam, characterized Rwandans as having loved the monarchy, and that only a handful of "radicals" had fought to have it abolished. Those radicals were often characterized by The Princess?? Or by all case-load refugees? as proponents of "genocide ideology," referencing a controversial legal prohibition introduced by the 
RPF to condemn acts intended to promote "ethnic divisionism" or minimize the severity of the 1994 genocide. $^{44}$

When asked why people loved the monarchy, and why the Belgians would have favored Hutu leadership, responses offered by old case-load returnees mostly aligned: "The King [Rudahigwa] stood up to them and refused to see his people divided." "The King" in all of these discussions reference Rudahigwa, The Good King. When we asked about other kings, either Musinga or Ndahindurwa, the narrators would always bring the discussion back to Rudahigwa, pointing to his principled stance against European-imposed ethnic and racial segregation.

\section{Mythico-History 2: Bloody Tyrants}

"Génocidaires," a distinctly Rwandan term used in reference to people who were convicted and imprisoned for committing serious crimes during the 1994 genocide, proved less conflicted in their representations of the Rwandan monarchy, which in their narratives was uniformly approached as a specifically Tutsi institution that was notable for its systemic oppression of the Hutu masses. ${ }^{45}$ From their vantage point

\footnotetext{
${ }^{44}$ Law No. 18/2008 defines genocide ideology as "an aggregate of thoughts characterized by conduct, speeches, documents and other acts aiming at exterminating or inciting others to exterminate people basing [sic] on ethnic group, origin, nationality, region, color, physical appearance, sex, language, religion or political opinion, committed in normal periods or during war." The prohibition against genocide ideology \#\# first mentioned in the 2003 Constitution, but not proscribed by law until 2008 \#\# is controversial due to the vague definition of the term and its widespread application to individuals who attempt to shed light on the RPF's various human rights abuses and lacking democratic reforms. Amnesty International, "Rwanda: Safer to Stay Silent: The Chilling Effect of Rwanda's Laws on 'Genocide Ideology' and 'Sectarianism”' (New York:
} Amnesty International Report, 2010) (http://www.amnesty.org/en/library/info/AFR47/005/2010/en, accessed 27 May 2013). 45 This term is adapted from the French "génocideur." 
in the Rwandan prison system, they tended to speak of "the king" as though only one king had ruled pre-colonial Rwanda, leaving little room to explore the specific personality traits or policies of individual monarchs and their advisors. Under the circumstances, génocidaires described the "Tutsi king" or "Tutsi monarchy" as uniformly evil, and as responsible for maintaining the economic, political, and ritual supremacy of the Tutsi minority at the expense of the Hutu majority. One prevalent story portrays the king as particularly bloodthirsty. Michel, a salesman, related the story of a Tutsi king who supported himself as he stood by planting his spear in the bodies of Hutu children. The children presumably died as a result of being mistreated in this manner. However, Michel remarked that this was inconsequential, as the king regularly sacrificed Hutu civilians for no reason other than they were inferior.

Philippe, a history teacher, related a similar story. However, where other génocidaires attributed this behavior to the king, Philippe claimed it was "the Queen Mother" who had abused Hutu children so abominably. Philippe was quick to accuse Rwandan women \#\# regardless of age, ethnicity, economic status, or regional background \#\# of poisoning people or manipulating their husbands and other men to commit criminal acts on their behalf, revealing a preoccupation with Rwandan women as poisoners, conspirators, and manipulators. His decision to attribute this behavior to the queen mother may have been rooted in his affiliation with the Hutu Power movement, which condemns Tutsi women for using their beauty, intelligence and good manners to trick Hutu men into servitude. ${ }^{46}$ Conversely, it may have emerged from the negative qualities attributed to Kanjogera, who in Rwandan history is remembered as an ambitious and bloodthirsty woman who not only facilitated German colonial ambitions, but conspired to murder those who

\footnotetext{
${ }^{46}$ Malkki, Purity and Exile.
} 
challenged her son's leadership using a large sword with which she was buried after her death. ${ }^{47}$

Variations on this iconic story were repeated by génocidaires across Rwanda to justify their participation in the genocide, and demonstrate the need for ongoing Hutu resistance to Tutsi oppression. Génocidaires often described the RPF and its treatment of the Hutu majority as a modern incarnation of the Tutsi monarchy, and therefore, Hutu oppression. They cited the "fact" that President Paul Kagame was descended from the Nyiginya clan as evidence that Rwanda was in the grips of a new Tutsi hegemony. ${ }^{48}$ Such sentiments were further influenced by personal experiences of mass atrocities perpetrated by RPF troops during Rwanda's 1990 to 1994 civil war and in the post-genocide period, family stories of the suffering endured under the Tutsi monarchy, and the education that many génocidaires had received under the Kayibanda and Habyarimana regimes. ${ }^{49}$

Rather than celebrating or dismissing these narratives in relation to their perceived historical accuracy (or lack thereof), a more valuable exercise lies in once again contextualizing these narratives in relation to the life histories of those who

${ }^{47}$ C. Newbury, The Cohesion of Oppression, 59; Des Forges, Defeat is the Only Bad News, 22\#\#23.

${ }^{48}$ In actual fact, Paul Kagame is descended from the Abakagara lineage of the Ega clan, which still connotes elite status in Rwanda society as having produced many of Rwanda's Queen Mothers, including the notorious Kanjogera. However perhaps, from the perspective of those génocidaires who were attempting to establish continuity between Kagame and the oppression monarchs of Rwanda's recent past, Kagame's Ega heritage lacks the same immediacy compared to the betterknown Nyiginya clan, which was the royal clan.

${ }^{49}$ Much like the RPF, Kayibanda and Habyarimana engaged in historical revisionism during their rule. However, the official narratives under Kayibanda and Habyarimana were demonized the Tutsi as a means of distracting the Rwandan people from the corruption and mismanagement that characterized their tenure. Catharine Newbury, "Ethnicity and the Politics of History in Rwanda," in: David Lorey and William Beezley (eds.), Genocide, Collective Violence, and Popular Memory (Wilmington: Scholarly Resources Inc., 2002), 67\#\#83. 
voiced them and the broader political climate in which they were produced. The vast majority of the estimated 140,000 génocidaires that have been imprisoned in postgenocide Rwanda are men who, during the 1994 genocide, were adults between the ages of twenty to forty-nine years of age, who supported themselves through subsistence farming. An estimated seventy-seven percent were parents with slightly higher levels of education and literacy than found among the average population. These findings \#\# consistent among the twenty-seven génocidaires who inform this article \#\# led Scott Straus to conclude that "Rwanda's perpetrators (...) were quite ordinary. They were average adult Hutu men \#\# in terms of age, education, paternity, and occupation." 50

Within this broader demographic profile, both Michel and Philippe had lived experiences that intimately affected how they constructed their narratives of the Tutsi monarchy. For his part, Michel's relatively peaceful and normal life had been suddenly upset by the RPF invasion of 1990, at which point Rwandan Patriotic Army (RPA) soldiers murdered his father, despite the fact that he was not part of the Hutu Power movement, nor had he ever publicly espoused anti-Tutsi sentiments. However, when attempting to justify his participation in the 1994 genocide, Michel cited not only his father's murder, but the more pressing danger of allowing Rwanda to fall once again into the hands of the Tutsi. His family had raised him on stories of the everyday oppression that the Hutu people had endured under the Tutsi monarchy. He was further inculcated with this theme as part of his education during the Kayibanda regime..$^{51}$

\footnotetext{
${ }^{50}$ Scott Straus, The Order of Genocide: Race, Power, and War in Rwanda (Ithaca: Cornell University Press, 2006), 107\#\#108.

${ }^{51}$ Many Rwandans claim to have first learned about their ethnicity and that of their neighbors as part of their education during the Kayibanda and Habyarimana regimes, when Tutsi students were required to identify themselves as part of history lessons aimed at teaching the students about
} 
Of particular importance, these abuses were not solely perpetrated by the Tutsi monarchy, but were intertwined with the fabric of everyday life in pre-colonial and colonial Rwanda. Michel cited the practice of ububake, wherein patronage networks were established through the gifting of cattle from a wealthy Tutsi to a (usually Hutu) subordinate who would in turn provide labor, a share of the returns, and political support to the patron as necessary. Michel interpreted this system as a form of slavery through which the Tutsi grew increasingly wealthy without having to burden themselves unnecessarily with manual labor. He argued that ubuhake allowed the Tutsi to justify the oppression of the Hutu masses. As simple farmers they were considered poorly mannered, stupid, and unattractive, and by the terms of ububake were afforded few opportunities to better themselves. Meanwhile the Tutsi were able to educate themselves, eat well, and avoid intense manual labor that might cause their bodies to degrade more rapidly. However, of these rumored practices, the king's alleged habit of stabbing Hutu children with his spear to support himself as he stood had particularly resonated with Michel, convincing him that the Tutsi should never be permitted to regain political and military power in Rwanda.

Philippe's life history was similarly complicated by personal experience of atrocities at the hands of the RPA, family narratives of suffering under Tutsi hegemony, and the education he received under the Kayibanda regime. Philippe was adamant that he, and the Hutu people more generally, were the real victims in Rwanda, a position he supported by citing endless human rights abuses he and his ancestors had endured at the hands of their Tutsi compatriots. He argued that life in pre-colonial and colonial Rwanda was difficult even for those Hutu who had no direct dealings with the Tutsi monarch, because the intricate system of chiefs and sub-chiefs \#\# all of whom he claimed were also Tutsi \#\# that dominated Rwanda.

Hutu oppression at the hands of the Tutsi. C. Newbury, "Ethnicity and the Politics of History in Rwanda." 
This hierarchy ensured that the Hutu remained uneducated and poor while allowing the Tutsi to claim the best of everything \#\# from crop yields to livestock to property \#\# in the name of the king. Those who resisted could be exiled or put to death for rejecting the king's authority. As a result, Philippe claimed that the Hutu majority had been forced to work nearly to death to meet the unreasonable demands of their Tutsi leaders.

As a history teacher who had been trained in the official histories that dominated under the Kayibanda and Habyarimana regimes, Philippe rarely distinguished between his family's oppression and those abuses he learned in school as part of government curriculum. However, he noted that his grandparents (and every generation that preceded them since the arrival of the Tutsi in Rwanda) were victims of slavery, forced by the Tutsi to carry hot pots on their heads and work endlessly for just enough food to sustain them, while the Tutsi kept the most fertile land for their cattle. Quality of life for the Hutu improved slightly under Belgian rule. And under Kayibanda, life in Rwanda improved further: unlike previous generations from his family, Philippe completed primary and secondary school, trained as a teacher, and by his mid-twenties could afford to marry, raise children, and maintain a small piece of land.

But the stories of oppression related to Philippe by his parents and grandparents offered lessons that were difficult for him to forget. When the RPA invaded Rwanda in 1990, Philippe was, for the first time in his life, overwhelmed with an intense fear of the Tutsi. He joined the local youth militia, the Interahamwe, with the intention of defending Rwanda from the Tutsi returnees who he believed were determined to reestablish a Tutsi monarchy and re-enslave the Hutu masses. Rumors of atrocities perpetrated by RPA troops against Hutu civilians in the north further convinced Philippe of the legitimacy of his beliefs. When Habyarimana was assassinated on 6 April 1994, extremists affiliated with his leadership claimed that the RPF was responsible for Habyarimana's assassination, and Philippe found no 
reason to doubt them. Realizing that the RPF was now close to gaining control of Rwanda, Philippe participated willingly in the massacre of Tutsi women, children, and elders who sought refuge in the local church, the hunting of Tutsi in the fields, forests, and swamps, the rape of Tutsi women, and the looting of Tutsi homes. The Tutsi were, in his estimation, the natural enemies of the Hutu people. However, Philippe simultaneously claimed that he rescued those Tutsi he knew were not a threat, providing food, information, and shelter for the duration of the genocide.

Despite the varied roles Philippe adopted during the 1994 genocide, Philippe presented himself first and foremost as a victim of the fear and uncertainty associated with living through three years of civil war; of the greed and opportunism that emerged from gaining status and wealth from the Tutsi he helped murder; of the RPF \#\# the "foreign Tutsi" who, upon wrestling control of the nation, held him accountable for the atrocities he perpetrated with their victor's justice; and of the international community whose apathy made it possible for him to linger in a Rwandan prison with neither basic human rights nor access to adequate legal representation. But first and foremost, Philippe perceived himself to be a victim of history. Philippe understood his involvement in the 1994 genocide as the inevitable outcome of generations of internalized anger, fear, and resentment toward the Tutsi. This legacy of victimization made it possible for him, an educated, devout Christian man with no prior criminal record, to participate in the massacre of unarmed Tutsi civilians. Furthermore, it left him with little remorse for his criminal actions during the 1994 genocide, viewing his imprisonment as further evidence of the unjust persecution of the Hutu majority by the privileged Tutsi \#\# now championed by the RPF.

\section{Mythico-History 3: A Complicated Figure}

Perhaps unsurprisingly, some Rwandans demonstrated a more conflicted understanding of the Rwandan monarchy, as evidenced by the story of Kamegeli's 
Rock. ${ }^{52}$ A popular Rwandan story, this narrative was first shared by a Rwandan colleague, Grégoire, during a regular trip to Nyanza in southern Rwanda. As we drove, he spoke of a non-specific Tutsi king who responded to the would-be brutality of his advisors with equal viciousness to discourage unnecessary brutality within his kingdom. Grégoire initially presented the king as a responsible and benevolent leader who upon having a rare criminal brought before him was unsure of how to respond. He decided to delegate the task of deciding upon an appropriate punishment to his most trusted advisor, Kamegeli. Much to his surprise, Kamegeli suggested a particularly brutal form of public execution that involved chaining the criminal to a large rock and leaving him to die slowly of exposure. The king was so horrified that he pardoned the criminal, and in his place sentenced Kamegeli to the very punishment he had devised. He was promptly tied to the large rock where he soon died.

While this narrative could be interpreted as a positive story intended to highlight the king's benevolent nature as evidenced by his response to the shocking brutality of his advisors, the story's ending demonstrates that the king was not above resorting to the same brutal punishment he claimed to eschew if he deemed it necessary. Given the complex light in which this unidentified monarch was portrayed, Grégoire's life history becomes crucial for revealing the political climate and personal experiences influencing his particular telling of this story.

Grégoire is an old case-load refugee who returned to Rwanda after the 1994 genocide. His family, descended from the royal Nyiginya clan, was forced to flee Rwanda during the ethnic and political violence that surrounded the 1959 Hutu

\footnotetext{
${ }^{52}$ The word kamegeri means "little mushroom" and references imegeri \#\# a type of mushroom that is grilled in a hot earthenware pan. Rose-Marie Mukarutabana argues this connection suggests that the story was invented by Rwandans as a parable of sorts, evoking the Rwandan equivalent of an “eye for an eye.” Personal communication, 2014.
} 
Revolution. His father was close to Ndahindurwa, who fled Rwanda in 1959 and who continues to live in exile. With his escape, Grégoire's family lost its patron and was forced to flee as well, first to Burundi, and later to the Democratic Republic of the Congo (DRC). Upon learning that the RPF was preparing to invade Rwanda in 1990, however, Grégoire joined the RPA, with whom he would fight for four years. Once the RPF had wrestled control of the nation, formally ending the 1994 genocide, Grégoire brought his wife and children to Rwanda. Soon after, he lost favor with his commanding officer for stealing, allegedly to supply the rapidly growing numbers of Rwandan recruits under his command. Grégoire served a minimal sentence, but while he considered the matter closed, he remained vigilant of the possibility that his past arrest could cause him to be labeled a political subversive at any time. As such, he was cautious about discussing RPF actions or policies in public settings, even among trusted colleagues and friends, lest his comments be interpreted as evidence of political dissidence.

Grégoire's narrative of the king's use of capital punishment was thus necessarily complicated. Rwanda's current political climate dictates that Rwandans be wary of appearing supportive of the monarchy, lest it be interpreted as evidence of their dissatisfaction with the RPF. Yet simultaneously, Rwandans must avoid appearing critical of the monarchy, lest it be interpreted as evidence that they have internalized the genocide ideology popularized under Hutu Presidents Grégoire Kayibanda and Juvénal Habyarimana, which condemned the monarchy as an instrument of Hutu oppression. Thus, Grégoire's particular narrative of Kamegeli's Rock can be interpreted as a politically appropriate way to engage with and preserve memories of the Rwandan monarchy \#\# highlighting positive and negative attributes of this institution without revealing the narrator to be particularly invested in either position.

Alexis Kagame's version of the story of Kamegeli's Rock, published in 1972, reveals similar themes: 
Wishing to practice exemplary justice by matching the punishment to the crime, the King once had the opportunity to issue two sentences that remain famous in our traditions. He asked his chiefs to suggest punishments for a range of crimes, but without specifically naming those crimes. Without revealing his intentions, he took particular note of the proposals put forward by chiefs Mikoranya and Kamegeli. Sometime later, the chiefs successively committed crimes, of nature of which is has since been forgotten. The King took the opportunity to inflict upon them the terrible punishments they devised. Kamegeli was grilled on a white hot rock. Ever since, this rock is called Kamegeli's Rock, located in Ruhango, close to Mutakara. As for Chief Mikoranya, a tall piece of markamia wood was made into a lever and placed outside a hut. Mikoranya's arms were tied behind his back using a cow tendon [or sinew] so that his elbows touched; a strong rope was attached to his arms, and then pulled through the roof of the hut and attached to the wood lever outside to create tension. Once the lever released, the unfortunate man was violently lifted in the air and suspended under the roof of the hut, where he died. $^{53}$

Kagame provides additional context in recounting this story, whose protagonist is identified as King Mibambwe Mutabazi Gisanura, also known as Gisanura the Just. ${ }^{54}$ Gisanura is a popular figure in Rwandan history due to his legacy of providing precolonial Rwandans with fair laws and judgment. His court at Mutakara gave rise to the Rwandan proverb "rwacirive i Mutakara" ("the case was tried in Mutakara"),

\footnotetext{
${ }^{53}$ Alexis Kagame, Un Abrégé de l'Etbno-Histoire du Rwanda (Butare, Rwanda: Editions universitaires du Rwanda, 1972), 123. Translation by authors and Rose-Marie Mukarutabana.

${ }^{54}$ Vansina, Antecedents, 99.
} 
which implies a situation has been considered with exceptional fairness and thoroughness, and the subsequent decision is beyond appeal. According to Kagame, Gisanura was particularly appreciated by his people for a range of humanitarian acts, such as taxing the rich to provide free meals to the poor, and travelers and visitors to the court whose stays were extended in order to allow him to fully consider the cases being brought before him. ${ }^{55}$

As in the case of Grégoire, Kagame's account of Kamegeli's Rock was narrated during a tense period in Rwanda's history. The notoriously anti-Tutsi regime of President Kayibanda was coming to a close amid allegations of corruption and regional favoritism, despite the regime's efforts to distract the public with the national security threat allegedly posed by the inyenzi invasions. ${ }^{56}$ As a Tutsi elite who actively championed the interests of the monarchy, Kagame's interest in preserving knowledge of the Rwandan monarchy was undoubtedly personally and politically motivated, as well as a matter of professional and intellectual interest. ${ }^{57}$ However, surrounding the 1959 Hutu Revolution, Kagame was also a vocal supporter of Rwandan independence who, in its aftermath, was permitted to hold a prominent position at the National University of Rwanda, despite the presence of a quota system that limited the number of Tutsi within the Rwandan government, military and education institutions. Under the circumstances, Kagame's complex narrative of the Kamegeli's Rock and the king's simultaneous impulses to eschew and enable two brutal forms of capital punishment, could be interpreted as the result of Kagame's tenuous position of privilege within the Kayibanda regime.

\footnotetext{
${ }^{55}$ Kagame, Abrégé, 123.

${ }^{56}$ The term inyenzi $i$ references Tutsi refugees who, after fleeing previous periods of ethnic and political tension in Rwanda, settled in neighboring countries where they gained political and military support and periodically tried to return to Rwanda by force.

${ }^{57}$ Claudine Vidal, “Alexis Kagame entre mémoire et histoire,” History in Africa 15 (1988), 493\#\#504.
} 


\section{Conclusion: Political Cleavages in the Everyday}

While valuable in their own right, the above mythico-histories are of great importance for their ability to reveal ongoing political, ethnic, and social tensions that are, in many ways, specific to post-genocide Rwanda. For example, the general reticence surrounding how ordinary Rwandans speak about the monarchy in public settings exposes the fear that characterizes everyday life in post-genocide Rwanda, particularly for those individuals who harbor political beliefs and lived experiences that do not mesh with the RPF's official narrative. ${ }^{58}$ While many Rwandans nonetheless do choose to tell their stories of Rwanda's past, they find subtle ways to navigate the inherent risks in storytelling. In the case of the story of Kamegeli's Rock, this was accomplished by balancing the positive and negative attributes of the Rwandan monarchy to create the impression that the speaker was neutral.

Still others used mythico-histories of the monarchy to resist Rwanda's current official narrative and assert their individual lived experiences. Among génocidaires, it was no longer necessary to find a politically appropriate way to speak about the monarchy as they were already being punished for their crimes. Thus, they spoke freely and perhaps even exaggerated their stories of the Rwandan monarchy to better highlight the dangers of Tutsi rule for Rwanda, and recast their criminal complicity in the 1994 genocide as justified. Among Rwandans who were intimately connected to the monarchy, however, the mythico-history seemed to have been constructed to have the opposite effect: infusing the listener with sense that the monarchy was a positive force in the lives of Rwandans, while diminishing those aspects of monarchical leadership that could have been harmful to emphasize the unexpected and disproportionate nature of the 1994 genocide.

\footnotetext{
${ }^{58}$ Cf. Thomson, Whispering Truth to Power, cf. Burnet, Genocide Lives in Us.
} 
However, these narratives are of additional value for their ability to highlight the challenges facing oral historians in post-genocide Rwanda. Because history in post-genocide Rwanda is highly politicized \#\# much more so than in previous periods in the nation's past \#\# and has such dangerous potential for ordinary Rwandans, oral historians must be cognizant of the possibility that much of the data they collect, and their subsequent interpretations, will be highly politicized as well. The use of multiple life history and thematic interviews and long-term observation can reduce the risks of this kind of contamination by allowing oral historians to better contextualize narratives in relation to the dynamic personal, social and political contexts in which they are produced. However, the impact of this climate in Rwanda can never be eliminated completely, nor can its ability to polarize researchers.

To this end, it is essential that current scholars be well-read in Rwanda's contested past, including the pre-colonial period, and particularly as written and debated in the pre-genocide period. The above narratives on the Rwandan monarchy clearly demonstrate that despite the dissemination of the RPF's official narrative in the post-genocide period, Rwandans remain invested \#\# at least in private \#\# in divergent versions of Rwandan history that align more closely with their lived experiences, inherited knowledge of the past, and political affiliations. As such, it becomes particularly important for historians to consider the full depth and complexity of Rwandan history as discussed in the pre-genocide period in order to better contextualize the data that will be made available to them in the coming years. In this recommendation, we are guided by David Newbury's recent warning, that in the aftermath of the 1994 genocide in Rwanda, we must critically examine historical narratives, lest they become simplified propaganda. ${ }^{59}$

\section{${ }^{59}$ THIS NOTE HAS DISAPPEARED. PLEASE REPAIR.}


References 